\title{
A genetic and morphological survey to trace the origin of Melipona beecheii (Apidae: Meliponini) from Cuba
}

\author{
William de Jesús May-ItzÁ ${ }^{1}$, Walberto Lóriga PeÑA ${ }^{2}$, Pilar DE LA RÚA ${ }^{3}$, \\ José Javier G. QUEZADA-EÚAN ${ }^{1}$ \\ ${ }^{1}$ Departamento de Apicultura, Facultad de Medicina Veterinaria y Zootecnia, Universidad Autónoma de Yucatán, Mérida \\ Yucatán México \\ ${ }^{2}$ Departamento de Prevención, Facultad de Medicina Veterinaria, Universidad Agraria de la Habana, Havana Cuba \\ ${ }^{3}$ Departamento de Zoología y Antropología Física, Facultad de Veterinaria, Universidad de Murcia, 30100 Murcia Spain
}

Received 26 February 2019 - Revised 5 September 2019 - Accepted 2 October 2019

\begin{abstract}
The stingless bee Melipona beecheii is extensively distributed across Mexico and Central America and the only Melipona found in the Greater Antilles. The aim of this work was to establish possible continental affinities of $M$. beecheii from the Antilles. We compared populations from the main island (Cuba) with two clearly separated genetic lineages of $M$. beecheii on mainland, namely the Yucatán peninsula (Mexico) and Costa Rica. We used morphometrics, the degree of cephalic maculation, and microsatellite variation. Results indicate a greater morphological and genetic similarity between populations from Cuba and the Yucatán peninsula with respect to those of Costa Rica. Based on our findings, we conclude that the origin of $M$. beecheii from Cuba is more likely the Yucatán peninsula (Mexico). We found evidence that isolation has not been large enough to result in a new genetic lineage.
\end{abstract}

\section{Melipona / morphology / microsatellites / Antilles / Mesoamerica}

\section{INTRODUCTION}

Stingless bees have been important for Mesoamerican civilizations as sources of food, medicine, and craft (Crane 1992; Quezada-Euán et al. 2001). The main species in Mesoamerica before European colonization was Melipona beecheii Bennett, 1831 (Quezada-Euán et al. 2018). Interestingly, in contrast with other areas of Mexico and Central America, this species continued being the most important bee for honey production in the Yucatán peninsula of Mexico even after the introduction of Apis mellifera by European colonizers (Michener 1979, 1982; Genaro 2008). In-

Corresponding author: W. May-Itzá, mayitza@correo.uady.mx

Manuscript editor: Klaus Hartfelder deed, European honey bees were not introduced into the Yucatán until the early part of the twentieth century because $M$. beecheii produced honey and cerumen in large quantities in this area (González-Acereto 2008).

The widely dispersed $M$. becheeii species coexists with Melipona variegatipes Gribodo, 1893 in the Antilles archipelago (Schwarz 1932) but showing a different distribution: while $M$. beecheii is presently reported in two of the Greater Antilles (Cuba, Jamaica) (Genaro and Lóriga 2018), the other species is found in the Lesser Antilles (Schwarz 1932; Camargo et al. 1988). Previous comparison of a few Melipona specimens from Cuba and the Yucatán peninsula led Schwarz (1932) to propose they belonged to the species M. becheeii due to morphological similarities. Given that colonies of the genus Melipona seem capable of rafting in their tree nests, a plausible hypothesis of the presence of $M$. becheeii on Cuba 
could be a continental origin given rise to a founding population on this oceanic island (Roubik and Camargo 2012). Another hypothesis explaining the presence of M. beecheii in the Greater Antilles is that colonies could have been introduced to Cuba during the Spanish rule of this area due to its economic importance in Mesoamerica (Michener 1979; Camargo et al. 1988). Both of those hypotheses would imply a recent origin of $M$. beecheii in Cuba and a lack of substantial differentiation with respect to continental populations. Alternatively, as the original Cuban bee fauna appears to have its origin during the Proto Antilles period millions of years ago (Genaro 2008), it could be that populations of $M$. beecheii may have an ancestral origin and, thus, exhibit substantial differentiation from continental populations. Indeed, Roubik and Camargo (2012) suggested that $M$. variegatipes found on Guadeloupe and Dominica may have arrived there from South America during the last glaciations.

Presently, $M$. beecheii has a distribution ranging from the Pacific and Gulf coasts of Mexico down to Costa Rica (Schwarz 1932; Ayala 1999; May-Itzá et al. 2012). Differentiation within the species $M$. becheeii is considered relatively high (Roubik and Camargo 2012) and molecular studies have revealed at least two clear genetic lineages of $M$. beecheii, one distributed in the Yucatán peninsula and Northern Chiapas in Mexico and the other from central Guatemala down to Costa Rica (May-Itzá et al. 2009, 2012). Given the existence of genetic lineages, it is important to analyze the genetic profile of the populations from Cuba to discern which ones are present in Cuba and if isolation events have given rise to substantial differentiation from continental populations. Because of the mode of reproduction, stingless bees have strong dispersal limitations (Rasmussen and Cameron 2010), and are therefore of particular interest for the study of relationships between islands and continents (Roubik and Camargo 2012). The study of bee populations located on islands is also of interest to understand aspects related to extinction risks, possible bottleneck effects, gene drift, and inbreeding in haplodiploid Hymenoptera (Alves et al. 2011; Francisco et al. 2016, 2017; Soro et al. 2017).

To trace the origin of $M$. beecheii from Cuba, we have analyzed $M$. beecheii populations from Cuba,
Mexico (Yucatán peninsula) and Costa Rica using morphometric characters, the degree of cephalic maculation, and molecular markers (microsatellites loci). If island populations have a more recent continental origin, we predict more morphometrical similarity between them and continental populations and lower allelic richness and heterozygosity in Cuban populations.

\section{MATERIALS AND METHODS}

\subsection{Sampling sites and collecting bees}

Samples of worker bees were collected from colonies of $M$. beecheii distributed in Cuba (30 colonies), Mexico (hereinafter referred to as Yucatán) (10 colonies), and Costa Rica (nine colonies) (Figure 1, Table I). Each sample consisted of 10-20 young workers collected directly from the brood chamber of managed colonies, which were preserved in absolute ethanol at $-20^{\circ} \mathrm{C}$.

\subsection{Morphometric and cephalic maculation analyses}

From 10 to 20 worker bees per colony were used for morphometric analysis. From each bee, the head, right forewing, the right hindwing, and the right posterior leg were dissected and mounted on slides. Eight morphometric characters (forewing length (FWL); forewing width (FWW); hindwing length (HWL); hindwing width (HWW); femur length (FL); tibia length (TL); tibia width (TW) and basitarsus width (BW)) were measured in accordance with the methodology of Quezada-Euán et al. (2007)

The same samples were discriminated according to their degree of cephalic maculation by determining the area covered with yellow color on the clypeus and supraclypeal malar areas using a scale of three levels: (1) scarce, yellow marks covering less than 10\%; (2) medium, yellow marks between 10 and 50\%; and (3) intense, yellow marks covering more than $50 \%$ as in Quezada-Euán et al. (2007). Images for morphometric and maculations were taken with a camera, Canon EOS 60D, connected to a microscope Leica S8APO and the software ImageJ V.1.50i. 


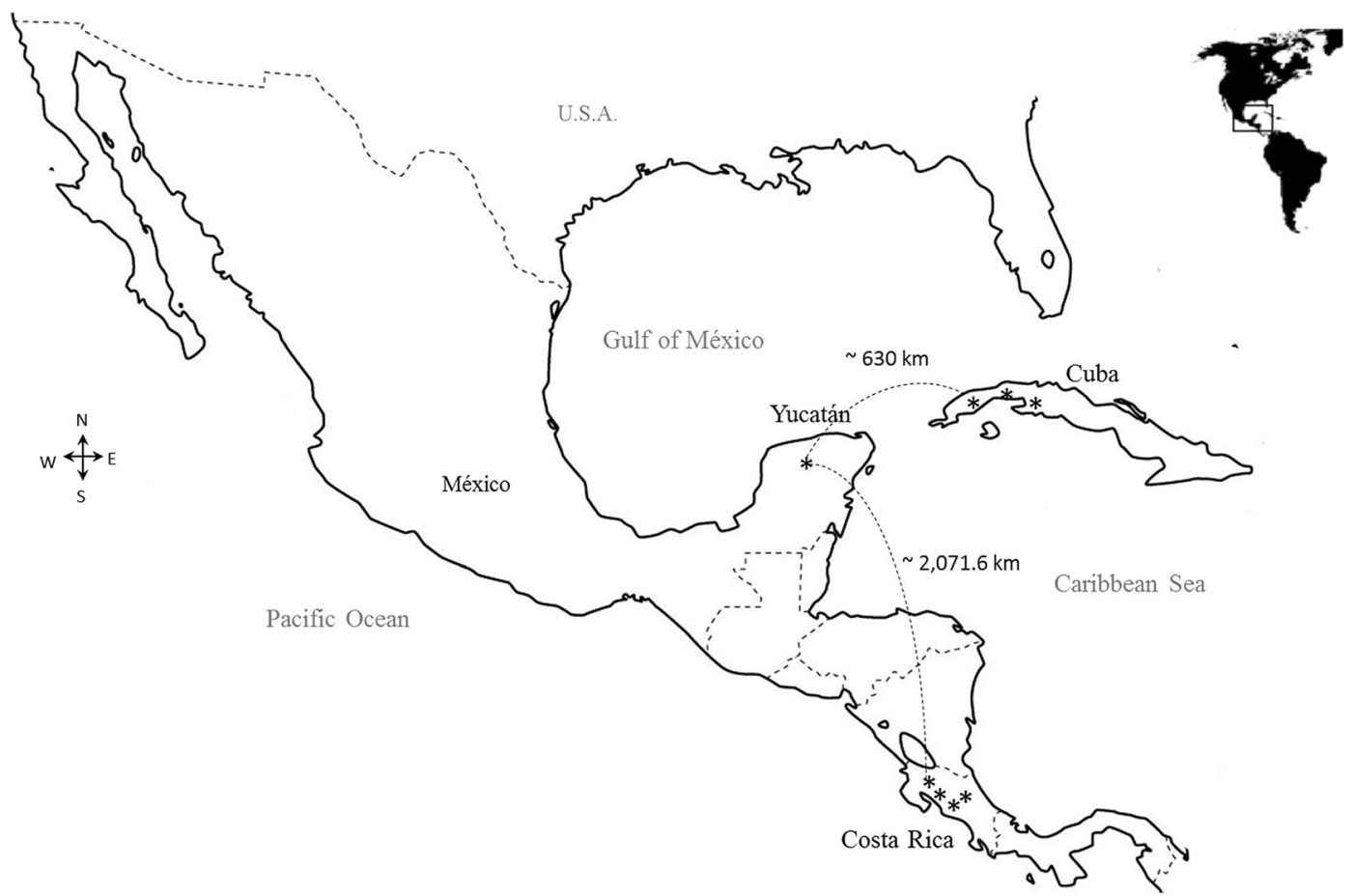

Figure 1. Locations and distance $(\sim \mathrm{Km})$ between collection sites of $M$. beecheii in Cuba, Yucatán, and Costa Rica.

\subsection{Molecular analysis}

Given the different number of colonies sampled in each country for the molecular analysis, one worker bee per colony from Cuba and five worker bees per colony (as in May-Itzá et al. 2010) from Yucatán and Costa Rica were used. Total DNA was extracted from three legs per worker using the DNeasy tissue kit (QIAGEN) and following manufacturer instructions. Two microliters out of a final dilution of $100 \mu \mathrm{l}$ was used for microsatellite amplification.

Seven microsatellite loci were amplified by two multiplex reactions. In the first reaction loci, T4-171 and T7-5 were amplified (Paxton et al. 1999) and in a second reaction loci, Mbi28, Mbi278, Mbi259, Mbi254, and Mbi201 (Peters et al. 1999) were amplified. Although these loci were not designed in $M$. beecheii, they have been used in this species previously with good success (Hurtado-Burillo et al. 2014). The conditions for amplification were $5 \mathrm{~min}$ at $95^{\circ} \mathrm{C}$, followed by 30 cycles of $30 \mathrm{sec}$. at $96^{\circ} \mathrm{C}, 30 \mathrm{sec}$. at $55^{\circ} \mathrm{C}$ (for the first reaction) or $57{ }^{\circ} \mathrm{C}$ (for the second reaction), $30 \mathrm{sec}$. at $72{ }^{\circ} \mathrm{C}$, and a final extension of $10 \mathrm{~min}$. at $72{ }^{\circ} \mathrm{C}$. Amplified fragments (= microsatellite alleles) were detected in an ABI PRISM 3100 sequencer (Applied Biosystem) and analyzed with the program Genemapper v3.7 (Applied Biosystem).

\subsection{Data analysis}

Morphometric data were analyzed using ANOVA to compare population (= all the colonies settled in one country) means for each measured character. Measure variation was studied using principal component analysis (PCA) as a reduction method to analyze body size globally. PCA uses the original variables to derive new noncorrelated variables. The components $\mathrm{PC} 1$ and PC2 were plotted to analyze the spatial distribution (Wiley 1981).

The number of alleles $(\mathrm{Na})$, private alleles (Npa), and expected heterozygosity (He) per microsatellite loci and per population were 
Table I. Collection information and number of colonies $(N)$ of $M$. beecheii sampled in Cuba, Yucatán, and Costa Rica.

\begin{tabular}{lllll}
\hline Country & Province & Locality & $N$ & Geographic coordinates \\
\hline Cuba & La Habana & Nueva Paz & 10 & $22^{\circ} 48^{\prime} \mathrm{N} 81^{\circ} 50^{\prime} \mathrm{O}$ \\
& & San Nicolás & 4 & $22^{\circ} 46^{\prime} \mathrm{N} 81^{\circ} 54^{\prime} \mathrm{O}$ \\
& & San José & 8 & $22^{\circ} 57^{\prime} \mathrm{N} 82^{\circ} 09^{\prime} \mathrm{O}$ \\
& & Jaruco & 4 & $23^{\circ} 02^{\prime} \mathrm{N} 82^{\circ} 00^{\prime} \mathrm{O}$ \\
& & Consolación de Sur & 2 & $22^{\circ} 30^{\prime} \mathrm{N} 83^{\circ} 30^{\prime} \mathrm{O}$ \\
México & Pinar del Río & Jaguey Grande & 2 & $22^{\circ} 03^{\prime} \mathrm{N} 81^{\circ} 07^{\prime} \mathrm{O}$ \\
Costa Rica & Matanzas & Mérida & 10 & $20^{\circ} 47^{\prime} \mathrm{N} 89^{\circ} 03^{\prime} \mathrm{O}$ \\
& Yucatán & Heredia & 1 & $10^{\circ} 28^{\prime} \mathrm{N} 84^{\circ} 01^{\prime} \mathrm{O}$ \\
& Heredia & Juntas de Abangares & 3 & $10^{\circ} 29^{\prime} \mathrm{N} 85^{\circ} 21^{\prime} \mathrm{O}$ \\
& Guanacaste & Atenas & 3 & $10^{\circ} 23^{\prime} \mathrm{N} 84^{\circ} 26^{\prime} \mathrm{O}$ \\
& Alajuela & Miramar & 2 & $9^{\circ} 13^{\prime} \mathrm{N} 83^{\circ} 20^{\prime} \mathrm{O}$ \\
\hline
\end{tabular}

calculated with the program GeneAlEx 6.1 (Peakall and Smouse 2006). Since this is the first analysis about morphometric and genetic differences between island and mainland $M$. beecheii populations and to avoid directionality, the twotailed Mann-Whitney $U$ Test (Mann and Whitney 1947) was used. Hardy-Weinberg and genotypic linkage equilibria, population differentiation using the Fisher's exact probability test, and Fst values were calculated in GENEPOP (Raymond and Rousset 1995).

We evaluated the presence of genetic clusters by applying DAPC (Jombart et al. 2010), a distancebased method implemented in the adegenet $\mathrm{R}$ package version 2.0.1 (Jombart 2008). This method is a non-model-based method that builds genetic clusters by synthesizing the original variables (alleles), and therefore, it does not assume HWE or linkage disequilibrium (Jombart et al. 2010). The ideal $K$ value (i.e. the number of clusters) is selected by the Bayesian information criterion (BIC) and the optimal $K$ value is identified through an accompanying decrease in the BIC (Jombart et al. 2010).

\section{RESULTS}

\subsection{Morphometrics and cephalic maculation}

The analysis of body size showed that samples of $M$. beecheii from Cuba are smaller than those from Costa Rica. However, the bees from Cuba were larger than those from Yucatán in six morphometric traits, except for the forewing width (FWW) and tibia length (TL) (Table II). Overall, these data show that bees from Cuba show differences regarding individual morphometric characters with bees from Costa Rica and Yucatán. The first two components of the PCA (1 and 2) explained $68.56 \%$ of the total variation in the morphometric traits. The first component explained $57.16 \%$ of the total variation and the second explained $11.40 \%$ of the variance. The values per bee for PC1 and PC2 showed a clear separation between $M$. beecheii from Cuba, the Yucatán, and Costa Rica (Table III). However, the overall analysis of body size using PCA revealed more similarities between the bees from Cuba and Yucatán (Figure 2), with an overlap between the morphometric characters of these populations of 95-99\% (Table II).

In relation to the facial maculation, the bees from Cuba and Yucatán displayed a similar degree of intense facial maculation (highly widespread and more than $50 \%$ on the clypeus and a large portion of the malar area in all bees from Yucatán and Cuban) compared with those from Costa Rica which had a lower degree of facial maculation (yellow marks absent in the face or scarce, with the yellow marks covering less than $10 \%$ of the clypeus). The degree of head maculation was particularly different between the bees from Costa 
Table II. ANOVA analysis comparison of the eight morphometric characters in populations of $M$. beecheii from Cuba, Yucatán (Mexico), and Costa Rica ( $N=$ number of colonies). Mean values \pm SE (standard error) are shown.

\begin{tabular}{llll}
\hline Character (mm) & $\begin{array}{l}\text { Cuba } \\
(N=30)\end{array}$ & $\begin{array}{l}\text { Yucatán (Mexico) } \\
(N=10)\end{array}$ & $\begin{array}{l}\text { Costa Rica } \\
(N=9)\end{array}$ \\
\hline Forewing length (FWL) & $7.21570 \pm 0.010^{\mathrm{b}[97 \%]}$ & $7.01998 \pm 0.017^{\mathrm{c}}$ & $7.79317 \pm 0.032^{\mathrm{a}}$ \\
Forewing width (FWW) & $2.49549 \pm 0.004^{\mathrm{b}[99 \%]}$ & $2.51110 \pm 0.007^{\mathrm{b}}$ & $2.75914 \pm 0.012^{\mathrm{a}}$ \\
Hind wing length (HWL) & $3.54515 \pm 0.005^{\mathrm{b}[97 \%]}$ & $3.44128 \pm 0.009^{\mathrm{c}}$ & $5.54055 \pm 0.016^{\mathrm{a}}$ \\
Hind wing width (HWW) & $1.48177 \pm 0.003^{\mathrm{b}[95 \%]}$ & $1.40837 \pm 0.005^{\mathrm{c}}$ & $1.54403 \pm 0.010^{\mathrm{a}}$ \\
Femur length (FL) & $2.35540 \pm 0.005^{\mathrm{b}[96 \%]}$ & $2.26783 \pm 0.009^{\mathrm{c}}$ & $2.53559 \pm 0.017^{\mathrm{a}}$ \\
Tibia length (TL) & $2.75616 \pm 0.005^{\mathrm{b}[99 \%]}$ & $2.74446 \pm 0.009^{\mathrm{b}}$ & $3.11183 \pm 0.017^{\mathrm{a}}$ \\
Tibia width (TW) & $1.19253 \pm 0.003^{\mathrm{b}[97 \%]}$ & $1.15915 \pm 0.006^{\mathrm{c}}$ & $1.23445 \pm 0.011^{\mathrm{a}}$ \\
Basitarsus width (BW) & $0.86560 \pm 0.002^{\mathrm{b}[96 \%]}$ & $0.83674 \pm 0.003^{\mathrm{c}}$ & $0.89186 \pm 0.007^{\mathrm{a}}$ \\
\hline
\end{tabular}

Different letters among a row indicate significant differences within means $(p<0.05)$

Values inside square brackets represent percentage of overlap between Cuban and Yucatecan populations

Rica and the bees from Cuba and Yucatán. The bees of Yucatán and Cuba showed a great similarity in the yellow maculation since in both cases this mark covered a great part of the malar area, periocular area, supraclypear area, and clypeus. In the Costa Rican bees, this maculation was reduced and, in most cases, almost absent, being remarkably different from Cuban and Yucatecan bees (Figure 3).

\subsection{Microsatellite data}

Only locus Mbi259 proved to be monomorphic in the population from Cuba, while the remaining six loci showed different levels of polymorphism. The average number of alleles per loci showed a high value in populations of Yucatán and Costa Rica (5.7 and 5.8, respectively) compared with that of Cuba (3.0). Mann-Whitney $U$ tests showed that differences in the number of alleles per loci were not significant between the populations of Yucatán and Costa Rica $(U=23.500, p=0.897)$ and between the samples from Cuba and Costa Rica $(U=15.000, p=0.218)$, while the number of alleles per loci was significantly different between the populations from Yucatán and Cuba $(U$ $=8.000, p=0.032)$. Although expected mean heterozygosity was higher in Costa Rica (0.548 $\pm 0.080)$ and Yucatán $(0.487 \pm 0.093)$ than in Cuba $(0.410 \pm 0.089)$ except for the locus Mbi254AAG (Table IV), no significant differences were obtained after Mann-Whitney $U$ tests.

The population from Cuba showed HardyWeinberg equilibrium $(p<0.05)$ values, while significant values in the Yucatán population were observed in four loci and in five loci in the population from Costa Rica, thus indicating an imbalance due to lack of heterozygotes. The loci were generally out of linkage disequilibrium after Bonferroni correction for each cluster, with the

Table III. Scores of the first two principal component of a PCA between M. beecheii populations from Cuba, Yucatán (Mexico), and Costa Rica ( $n=$ number of analyzed individuals). Mean values \pm SE (standard error) are shown

\begin{tabular}{llll}
\hline Character & $\begin{array}{l}\text { Cuba } \\
n=300\end{array}$ & $\begin{array}{l}\text { Yucatán (Mexico) } \\
n=100\end{array}$ & $\begin{array}{l}\text { Costa Rica } \\
n=30\end{array}$ \\
\hline Component 1 & $-0.0432 \pm 0.037^{\mathrm{b}}$ & $-0.6541 \pm 0.065^{\mathrm{c}}$ & $2.6543 \pm 0.120^{\mathrm{a}}$ \\
Component 2 & $0.3554 \pm 0.044^{\mathrm{a}}$ & $-0.4883 \pm 0.077^{\mathrm{b}}$ & $-2.0015 \pm 0.142^{\mathrm{c}}$ \\
\hline
\end{tabular}

Distinct letters in the same row indicate significant differences $(p<0.05)$ 


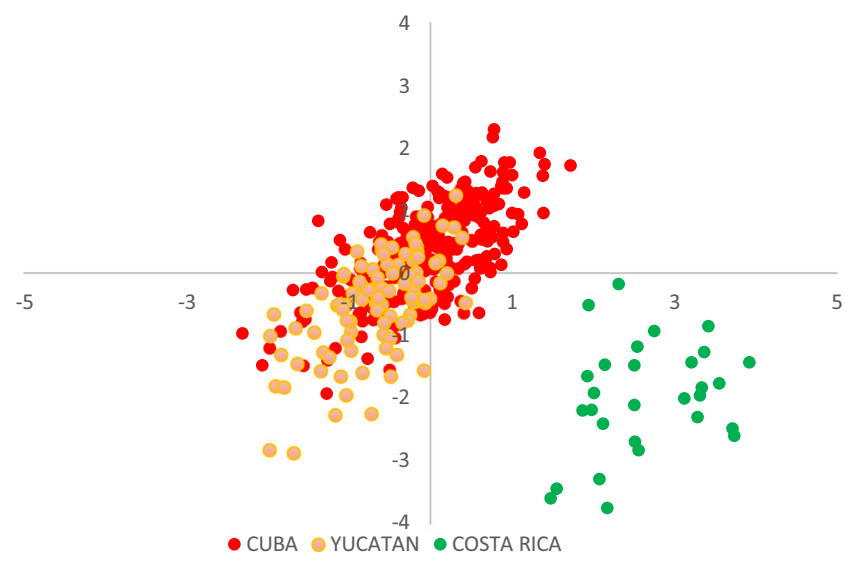

Figure 2. Distribution of PCA scores of $M$. beecheii colonies from Cuba, Yucatán, and Costa Rica against components 1 and 2 based on morphometric data.

exceptions of three out of the 15 pairwise comparisons in the population from Cuba and four and five out of the 21 pairwise comparisons in the population from Yucatán and Costa Rica, respectively.

The three populations differ significantly in the gene and genetic differentiation tests $(p<0.05$ for each population pair across all loci in both cases), a result that is supported by Fst pairwise values that were higher between Cuba and Costa Rica (0.417) than between Yucatán and Costa Rica (0.354) and Cuba and Yucatán (0.234). In congruence with these results, the decrease in the BIC number suggests two as the most probable number of clusters (Figure 4a). In this sense, individuals from Cuba and Yucatán conform a cluster with the exception of one individual that could have been translocated (either a mistake in the analysis or a hive that was moved from Costa Rica to Yucatán by stingless beekeepers) (Figure 4b). We also analyzed the assignment result when three clusters are considered, and a geographical separation was obtained (data not shown).

\section{DISCUSSION}

This research has shown that $M$. beecheii from Cuba showed fewer morphometric divergences in relation to those from Yucatán (México), while Costa Rican bees are generally larger in body size than Cuban and Yucatán bees. In addition, Cuban and Yucatán bees also showed greater similarity in relation to the extent of the yellow maculation on the face that was noticeably visible in the malar and periocular region and around the clypeus. However, in the bees of Costa Rica, the yellow color was less intense and the extension smaller and even in some cases it was observed that they lacked maculation, which coincides with previous findings of Quezada-Euán et al. (2007) when comparing $M$. beecheii from Yucatán and Costa Rica. Furthermore, morphometric differences have been documented between M. beecheii populations of Costa Rica and Yucatán (Quezada-Euán et al. 2007; May-Itzá et al. 2012), but there was no adequate morphometric study including samples of M. beecheii from Cuba. In this sense, our study has demonstrated that bees from Cuba have a smaller body size than those from Costa Rica, since the eight morphometric characters evaluated resulted with significant differences. Morphometric differences in body size are possibly an adaptive response to the local environment, as observed in several insect groups (Arnett and Gotelli 1999; Stillwell et al. 2007; Abbasi et al. 2009) and other stingless bee species (Rinderer et al. 1991; Batalha-Filho et al. 2010; Tan et al. 2016). Despite the observed variation in some morphometric traits of the stingless bee populations of $M$. beecheii from Cuba and Yucatán, the base of the morphometric 

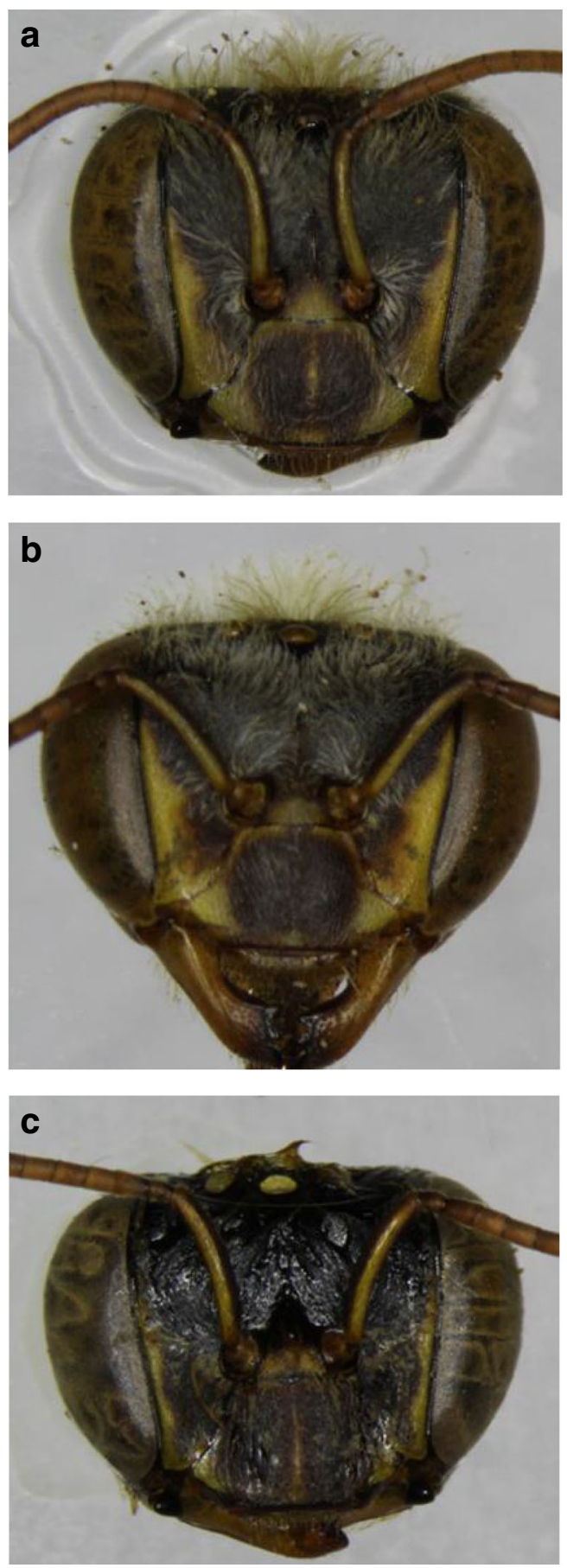

Figure 3. Maculation on the head of $M$. beecheii from Cuba (a), Yucatán (b), and Costa Rica (c).

structure of the species is still maintained. We could therefore conclude that in principle, the geographic isolation must have been recent as no incipient features of morphological differentiation are observed.

In relation to molecular data, the genetic similarity between the Cuban and Yucatecan populations is clearly reflected in the results of the Fst and DAPC analyses. The samples from Cuba and Yucatán formed a similar group based on these molecular and previously discussed morphometric data. The concordance between molecular and morphometric traits and cephalic coloration supports the hypothesis of human introduction of this stingless bee into the Greater Antilles from the closer continental Yucatán.

The smaller number of alleles observed in Cuba could be the effect of the absence of new population introductions, which results in no change of their genetic composition. Other situations such as geographic isolation may also have a relevant impact on the genetic diversity of island populations (Hedrick 2000). Another explanation for the low number of microsatellite alleles could be the result of a bottleneck event resulting from only a few colonies being translocated to Cuba. This could be happening due to adaptation process, distribution, and expansion of the population (Frankham 1997; Hedrick 2000; Batalha-Filho et al. 2010) that was introduced in the Cuban island.

A Bayesian molecular clock suggests that M. beecheii, possibly diverged from Melikerria congeners by late Miocene (Ramírez et al. 2010) and, thus, its ancestral population may have already been in place well before the Panama isthmus arose (Roubik and Camargo 2012). Nonetheless, the differentiation we observed between $\mathrm{Cu}$ ban and continental populations of $M$ beecheii does not suggest a Mioecene origin of the species in Cuba but rather a more recent one. Overall, these results considerately agree with Michener's (1979) hypothesis of recent introduction of $M$. beecheii to the Cuban island by native pre-Columbians or by the first Spanish colonizers, also matching with Schwarz (1948) and Camargo et al. (1988) assumptions. Under this context, Genaro (2008) proposed that once the 
Table IV. Summary statistics for the populations of M. beecheii from Cuba, Yucatán (Mexico), and Costa Rica. Sample size $(N)$, number of detected alleles per population $(\mathrm{Na})$, number of private alleles $(\mathrm{Npa})$, and expected heterozygosity $(\mathrm{He})$. Mean values $\pm \mathrm{SE}$ (standard error) are shown for each population

\begin{tabular}{|c|c|c|c|}
\hline Population & Cuba & Yucatán (Mexico) & Costa Rica \\
\hline \multicolumn{4}{|l|}{ T4-171 } \\
\hline$N$ & 26 & 51 & 31 \\
\hline $\mathrm{Na}$ & 2 & 3 & 3 \\
\hline Npa & 0 & 0 & 1 \\
\hline $\mathrm{He}$ & 0.426 & 0.503 & 0.614 \\
\hline \multicolumn{4}{|l|}{$\mathrm{T} 7-5$} \\
\hline$N$ & 24 & 51 & 31 \\
\hline $\mathrm{Na}$ & 3 & 7 & 2 \\
\hline $\mathrm{Npa}$ & 1 & 30 & 0 \\
\hline $\mathrm{He}$ & 0.570 & 0.654 & 0.225 \\
\hline \multicolumn{4}{|c|}{ Mbi201AAG } \\
\hline$N$ & 30 & 49 & 38 \\
\hline $\mathrm{Na}$ & 3 & 5 & 9 \\
\hline $\mathrm{Npa}$ & 3 & 4 & 8 \\
\hline $\mathrm{He}$ & 0.558 & 0.477 & 0.839 \\
\hline \multicolumn{4}{|c|}{ Mbi254AAG } \\
\hline$N$ & 30 & 55 & 41 \\
\hline $\mathrm{Na}$ & 4 & 8 & 7 \\
\hline $\mathrm{Npa}$ & 0 & 4 & 4 \\
\hline $\mathrm{He}$ & 0.713 & 0.680 & 0.643 \\
\hline \multicolumn{4}{|c|}{ Mbi259AAG } \\
\hline$N$ & 30 & 53 & 39 \\
\hline $\mathrm{Na}$ & 1 & 5 & 2 \\
\hline $\mathrm{Npa}$ & 0 & 3 & 0 \\
\hline $\mathrm{He}$ & 0.000 & 0.222 & 0.355 \\
\hline \multicolumn{4}{|l|}{ Mbi278AAG } \\
\hline$N$ & 26 & 52 & 41 \\
\hline $\mathrm{Na}$ & 4 & 9 & 11 \\
\hline Npa & 4 & 3 & 5 \\
\hline $\mathrm{He}$ & 0.332 & 0.772 & 0.698 \\
\hline \multicolumn{4}{|l|}{ Mbi28AAG } \\
\hline$N$ & 29 & 46 & 41 \\
\hline $\mathrm{Na}$ & 4 & 3 & 7 \\
\hline $\mathrm{Npa}$ & 2 & 1 & 4 \\
\hline $\mathrm{He}$ & 0.276 & 0.104 & 0.460 \\
\hline \multicolumn{4}{|l|}{ Mean \pm SE } \\
\hline$N$ & $27.857 \pm 0.937$ & $51.000 \pm 1.091$ & $37.429 \pm 1.716$ \\
\hline $\mathrm{Na}$ & $3.000 \pm 0.436$ & $5.714 \pm 0.892$ & $5.857 \pm 1.353$ \\
\hline $\mathrm{Npa}$ & $1.428 \pm 0.612$ & $2.571 \pm 0.571$ & $3.143 \pm 1.122$ \\
\hline $\mathrm{He}$ & $0.410 \pm 0.089$ & $0.487 \pm 0.093$ & $0.548 \pm 0.080$ \\
\hline
\end{tabular}




\section{a}

Value of BIC

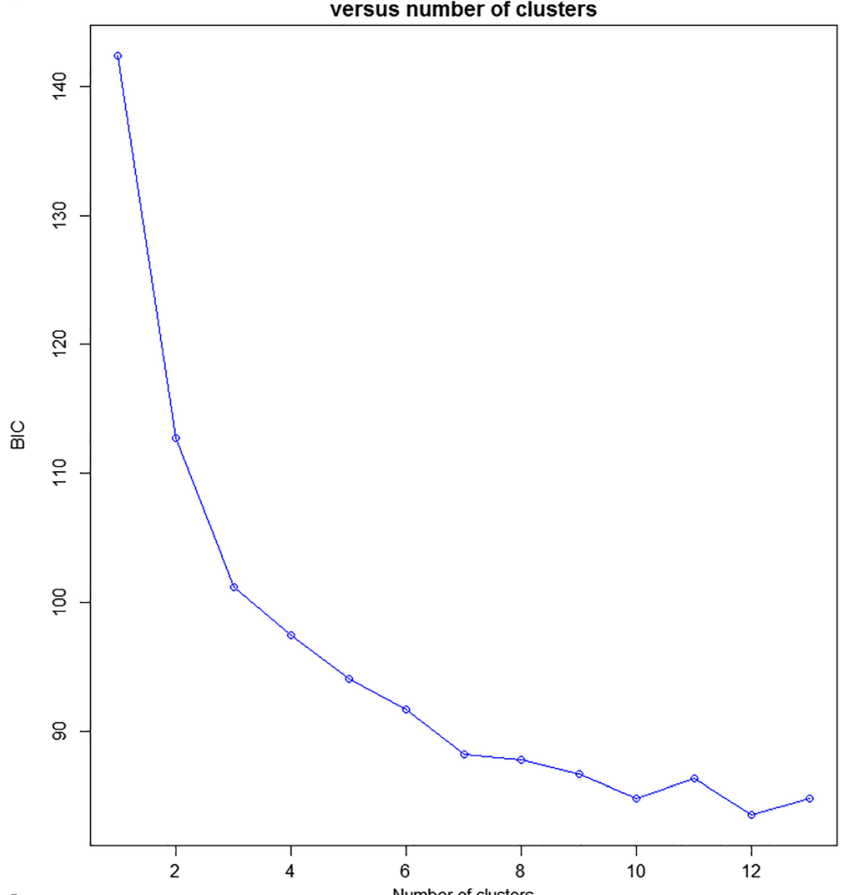

b

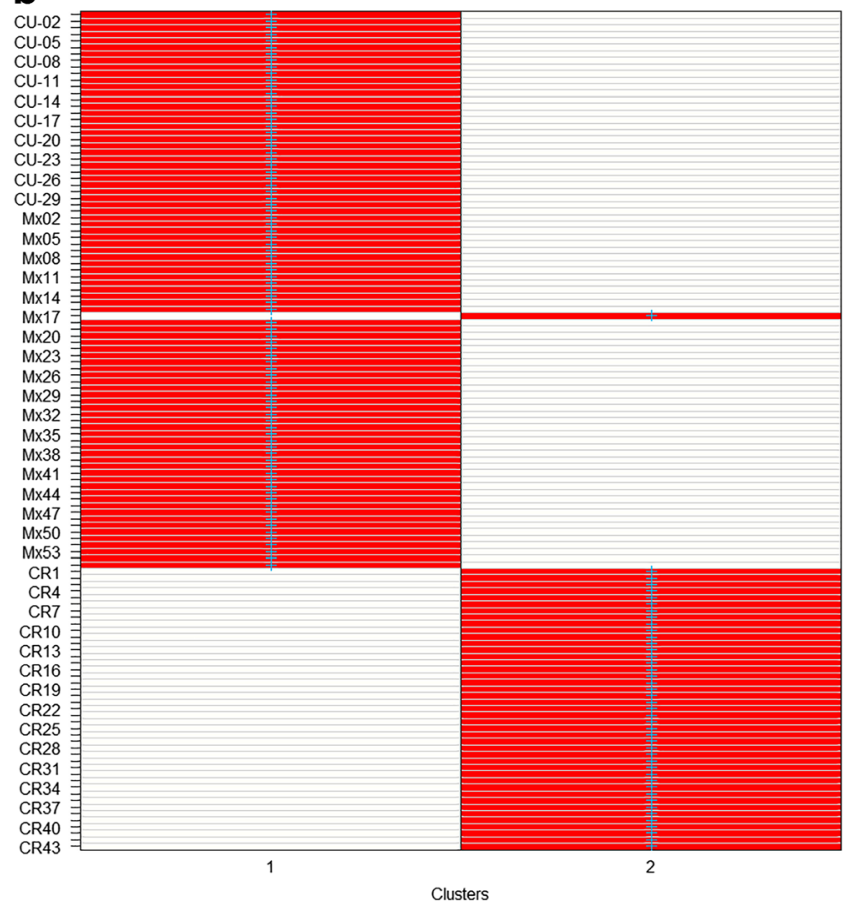

Figure 4. a Value of BIC (Bayesian information criterion) versus number of clusters. b Bar plot showing the discriminant analysis of principal components (DAPC) for all populations (populations from Cuba and Yucatán in grey and from Costa Rica in red). 
Spaniards established in Cuba and with the purpose of supplying themselves with honey and wax, they introduced $M$. beecheii to the Cuban island. With the base of phenotypic and molecular evidence, we suggest that the origin of the stingless bee $M$. beecheii from the Cuban islands is the Yucatán peninsula (Mexico).

Although there are no signs of incipient differentiation in the Cuban population of $M$. beecheii, it is important to promote measures to conserve these island populations and prevent the introduction of continental populations. Currently, there is no evidence of exchange of colonies between the continent and the Cuban island (Genaro and Lóriga 2018) but considering that bees are key to maintaining the health of ecosystems, knowledge of their genetic composition is a priority to establish measures for preservation and management of the population of stingless bees on the Cuban island. In the Yucatan Peninsula, advances in the application of management techniques have shown good results for a promising future of stingless beekeeping (González-Acereto et al. 2006). In this sense, it is suggested that also in Cuba, stingless beekeepers may apply division techniques to increase the number of colonies and thus stop the removal of nests in forests in order to conserve wild nests (Genaro and Lóriga 2018). In addition to using $M$. beecheii for honey production, its potential as an agricultural crop pollinator should be exploited on this island (Genaro 2008; Genaro and Lóriga 2018) where meliponiculture is gaining more interest.

\section{ACKNOWLEDGMENTS}

We thank the stingless beekeepers of Cuba, Costa Rica, and Yucatán for providing the samples; T. Solís Sánchez for his support with the photos; and Obdulia Sánchez Domingo and Vicente MartínezLópez for their help with the molecular analysis. Two anonymous reviewers and the editor (Dr. Klaus Hartfelder) made comments that greatly improved the manuscript.

\section{FUNDING INFORMATION}

This research has been funded by the Regional Government of Murcia (Fundación Séneca; Grant Number 19908/GERM/2015), CONACYT 103341, and CONACYT-SAGARPA- 291333/ 2018.

Une étude génétique et morphologique pour retracer l'origine de Melipona beecheii (Apidae: Meliponini) de Cuba

Melipona / morphologie / microsatellites / Antilles / Méso-Amérique

Eine genetische und morphologische Untersuchung zur Herkunft von Melipona beechei in Kuba

Melipona / Morphologie / Microsatelliten / Antillen / Mesoamerika

\section{REFERENCES}

Abbasi, R., Mashhadikhan, M., Abbasi, M., Kiabi, B. (2009) Geometric morphometric study of populations of the social wasp, Polistes dominulus (Christ, 1791) from Zanjan province, north-west Iran. N. Z. J. Zool. 36, 41-46.

Alves, D.A., Imperatriz-Fonseca, V.L., Francoy, T.M., SantosFilho, P.S., Billen, J., Wenseleers, T. (2011) Successful maintenance of a stingless bee population despite a severe genetic bottleneck. Conserv. Genet. 12, 647-658.

Arnett, A. E., Gotelli, N. J. (1999) Geographic variation in life history traits of the ant lion, Myrmeleon immaculatus: evolutionary implications of Bergmann's rule. Evolution 53,1180-1188.

Ayala, R. (1999). Revisión de las abejas sin aguijón de México (Hymenoptera: Apidae: Meliponini). Fol. Entomol Mex. 106: 1-123.

Batalha-Filho, H., Waldschmidt, A.M., Campos, L.A.O., Tavares, M.G., Fernandes-Salomão, T.M. (2010) Phylogeography and historical demography of the neotropical stingless bee Melipona quadrifasciata (Hymenoptera, Apidae): incongruence between morphology and mitochondrial DNA. Apidologie 41, 534-547.

Camargo, J.M.F., Moure, J.S., Roubik, D.W. (1988) Melipona yucatanica New Species (Himenoptera: Apidae: Meliponinae): stingless bee dispersal across the Caribbean Arc and Post-Eucene Vicariance. PanPac Entomol. 64, 147-157. 
Crane, E. (1992) The past and present status of beekeeping with stingless bees. Bee World. 73, 27-39.

Francisco, F. O., Santiago, L. R., Mizusawa, Y. M., Oldroyd, B. P., \& Arias, M. C. (2016). Genetic structure of island and mainland populations of a Neotropical bumble bee species. J. Insect Conserv., 20(3), 383394.

Francisco, F. O., Santiago, L. R., Mizusawa, Y. M., Oldroyd, B. P., \& Arias, M. C. (2017). Population structuring of the ubiquitous stingless bee Tetragonisca angustula in southern Brazil as revealed by microsatellite and mitochondrial markers Insect Sci. 24, 877890

Frankham, R. (1997) Do island populations have less genetic variation than mainland populations? Heredity. 78 (3), 311-327.

Genaro, J.A. (2008) Origins, composition and distribution of the bees of Cuba (Hymenoptera: Apoidea: Anthophila). Insecta Mundi. 52,1 -16.

Genaro, J.A., Lóriga, W. (2018). Melipona beecheii Bennett (Hymenoptera: Apidae): origen, estudios y meliponicultura en Cuba. Insecta Mundi. 643, 1-18.

González-Acereto, J.A., Quezada-Euán, JJG., Medina-Medina, L.A. (2006). New perspectives for stingless beekeeping in the yucatan: results of an integral program to rescue and promote the activity. Journal of Apicultural Research 45 (4):234-239.

González-Acereto, J. A. (2008) Cría y manejo de abejas nativas sin aguijón en México. Edit. Secretaria de Fomento Agropecuario y Pesquero, Mérida, México.

Hedrick, P.W. (2000) Genetics of populations. Second Edition. Jones and Bartlett Publishers

Hurtado-Burillo, M., Martinez, J., May-Itzá, W. D. J., Quezada-Euán, J. J. G., De la Rúa, P. (2014). Study of microsatellite markers in stingless bees Melipona colimana and $M$. beecheii from Mesoamerica. Archivos de Zootecnia, 63(241), 145-151.

Jombart, T. (2008). adegenet: a R package for the multivariate analysis of genetic markers. Bioinformatics, 24(11), 1403-1405. doi: https://doi.org/10.1093 /bioinformatics/btn129

Jombart, T., Devillard, S., Balloux, F. (2010). Discriminant analysis of principal components: a new method for the analysis of genetically structured populations. BMC Genet., 11(1), 94. doi: https://doi.org/10.1186/14712156-11-94

Mann, H.B., Whitney, D.R. (1947) On a Test of Whether One of Two Random Variables Is Stochastically Larger than the Other. Ann. Math. Stat. 18, 50-60.

May-Itzá, W. de J, Quezada-Euán, J.J.G., Enríquez, E., De la Rúa, P. (2009). Intraspecific variation in the stingless bee Melipona beecheii assessed with PCR-RFLP of the ITS1 ribosomal DNA. Apidologie. 40, 549-555.

May-Itzá, W. de J., Quezada-Euán, J.J.G., Medina, L.M.; Enríquez, E., De la Rúa, P. (2010). Morphometric and genetic differentiation in isolated populations of the endangered Mesoamerican stingless bee Melipona yucatanica (Hymenoptera: Apoidea) suggest the existence of a two species complex. Conserv. Genet. 11, 2079-2084.

May-Itzá, W. de J., Quezada-Euán, J.J.G., Ayala, R., De La Rúa, P. (2012) Morphometric and genetic analyses differentiate Mesoamerican populations of the endangered stingless bee Melipona beecheii (Hymenoptera: Meliponidae) and support their conservation as two separate units. J. Insect Conserv. 16, 723-731.

Michener, C. D. (1979) Biogeography of the bees. Ann. Missouri Bot. Gard. 66, 277-347.

Michener, C.D. (1982) A new interpretation of fossil social bee from the Dominican Republic. Sociobiology. 7, $37-45$.

Paxton, R.J., Weibschuh, N., Quezada-Euán, J.J.G. (1999) Characterization of dinucleotide microsatellite loci for stingless bees. Mol. Ecol. 8, 690-692.

Peakall, R., Smouse, P.E. (2006) GENEALEX 6: genetic analysis in Excel. Population genetic software for teaching and research. Mol. Ecol. Notes 6, 288-295.

Peters, J.M., Queller, D.C., Imperatriz-Fonseca, V.L., Roubik, D.W., Strassmann, J.E. (1999) Mate number, kin selection and social conflicts in stingless bees and honeybees. Proc. R. Soc. Lond. B 266, 379-38.

Quezada-Euán, J.J.G., May-Itzá, W. de J, GonzálezAcereto, J.A. (2001) Meliponiculture in Mexico: problems and perspective for development. Bee World. 82(2), 160-167.

Quezada-Euán, J.J., Paxton, R.J., Palmer, K.A., May-Itzá, W. de J, Tay, W.T., Oldroyd, B.P. (2007) Morphological and molecular characters reveal differentiation in a Neotropical social bee, Melipona beecheii (Apidae:Meliponini). Apidologie. 38, 1-2.

Quezada-Euán, J.J.G., Nates-Parra, G., Maués, M.M., Imperatriz-Fonseca, V.L., Roubik, D.W. (2018) The economic and cultural values of stingless bees (Hymenoptera: Meliponini) among ethnic groups of tropical America. Sociobiology. 65(4), 534-557.

Ramírez, S. R., Nieh, J. C., Quental, T. B., Roubik, D. W., Imperatriz-Fonseca, V. L., Pierce, N. E. ( 2010). A molecular phylogeny of the stingless bee genus Melipona (Hymenoptera: Apidae). Mol. Phylogenet. Evol. 56, 519 - 525.

Rasmussen, C., Cameron, S. A. ( 2010). Global stingless bee phylogeny supports ancient divergence, vicariance, and long distance dispersal. Biol. J. Linn. Soc. 99, $206-232$

Raymond, M, Rousset, F. (1995) GENEPOP (version 1.2): population genetics software for exact tests and ecumenicism. J. Hered. 86, 248-249

Rinderer, T.E., Stelzer, J.A., Oldroyd, B.P., Buco, S.M., Rubik, W.L. (1991) Hybridization between European and Africanized honey bees in the neotropical Yucatán peninsula. Science. 253, 309-311.

Roubik, D.W., Camargo, J.M.F. (2012). The Panama microplate,island studies and relictual species of Melipona (Melikerria) (Hymenoptera: Apidae: Meliponini). Syst. Entomol. 37, 189-199. 
Schwarz, H.F. (1932) The genus Melipona, the type genus of the Meliponidae or stingless bees. Bull. Am. Mus. Nat. Hist. 63, 231- 460.

Schwarz, H. F. (1948) Stingless Bee s (Meliponidae) of the Western Hemisphere. Bull. Am. Mus. Nat. Hist. 90, 1546.

Soro, A., Quezada-Euan, J. J. G., Theodorou, P., Moritz, R. F., \& Paxton, R. J. (2017). The population genetics of two orchid bees suggests high dispersal, low diploid male production and only an effect of island isolation in lowering genetic diversity. Conserv. Genet., 18(3), 607-619.

Stillwell, R.C., Morse, G.E., Fox, C. W. (2007) Geographic variation in body size and sexual size dimorphism of a seed-feeding beetle. Am. Nat. 170, 358-69.
Tan, K., Qu, Y., Wang, Z., Liu, Z., Engel, M.S. (2016) Haplotype diversity and genetic similarity among populations of the eastern honey bee from HimalayaSouthwest China and Nepal (Hymenoptera: Apidae). Apidologie. 47, 197-205.

Wiley, E.O. (1981) Phylogenetics, The theory and practice of phylogenetics systematics. New York: John Wiley and Sons.

Publisher's note Springer Nature remains neutral with regard to jurisdictional claims in published maps and institutional affiliations. 